\title{
Anaerobic killing of mucoid Pseudomonas aeruginosa by acidified nitrite derivatives under cystic fibrosis airway conditions
}

\author{
Sang Sun Yoon, ${ }^{1}$ Ray Coakley, ${ }^{2}$ Gee W. Lau, ${ }^{3}$ Sergei V. Lymar, ${ }^{4}$ Benjamin Gaston, ${ }^{5,6}$ \\ Ahmet C. Karabulut, ${ }^{1}$ Robert F. Hennigan, ${ }^{7}$ Sung-Hei Hwang, ${ }^{1}$ Garry Buettner, ${ }^{8}$ Michael J. Schurr, ${ }^{9}$ \\ Joel E. Mortensen, ${ }^{10}$ Jane L. Burns, ${ }^{11}$ David Speert, ${ }^{12}$ Richard C. Boucher, ${ }^{2}$ and Daniel J. Hassett' \\ ${ }^{1}$ Department of Molecular Genetics, Biochemistry, and Microbiology, University of Cincinnati College of Medicine, Cincinnati, Ohio, USA. \\ ${ }^{2}$ Cystic Fibrosis Pulmonary Research and Treatment Center and Department of Pulmonary Biology, University of North Carolina, \\ Chapel Hill, North Carolina, USA. ${ }^{3}$ Pulmonary Biology, University of Cincinnati College of Medicine, Cincinnati, Ohio, USA. \\ ${ }^{4}$ Department of Chemistry, Brookhaven National Laboratory, Upton, New York, USA. ${ }^{5}$ Department of Cell Biology, University of Cincinnati \\ College of Medicine, Cincinnati, Ohio, USA. ${ }^{6}$ Department of Pediatric Critical Care, University of Virginia School of Medicine, Charlottesville, Virginia, USA. \\ ${ }^{7}$ Department of Pharmacology and Biological Chemistry, Mount Sinai School of Medicine, New York, New York, USA. ${ }^{8}$ Department of Chemistry, \\ University of lowa, lowa City, lowa, USA. ${ }^{9}$ Department of Microbiology, Tulane University, New Orleans, Louisiana, USA. ${ }^{10}$ Department of Pediatrics, \\ Pathology and Laboratory Medicine, Children's Hospital, Cincinnati, Ohio, USA. ${ }^{11}$ Infectious Diseases Section, Children's Hospital and Regional Medical Center, \\ Seattle, Washington, USA. ${ }^{12}$ Department of Pedriatrics, University of British Columbia, Vancouver, British Columbia, Canada.
}

\begin{abstract}
Mucoid, mucA mutant Pseudomonas aeruginosa cause chronic lung infections in cystic fibrosis (CF) patients and are refractory to phagocytosis and antibiotics. Here we show that mucoid bacteria perish during anaerobic exposure to $15 \mathrm{mM}$ nitrite $\left(\mathrm{NO}_{2}^{-}\right)$at $\mathrm{pH} 6.5$, which mimics $\mathrm{CF}$ airway mucus. Killing required a $\mathrm{pH}$ lower than 7, implicating formation of nitrous acid $\left(\mathrm{HNO}_{2}\right)$ and $\mathrm{NO}$, that adds $\mathrm{NO}$ equivalents to cellular molecules. Eighty-seven percent of CF isolates possessed mucA mutations and were killed by $\mathrm{HNO}_{2}(3-\log$ reduction in 4 days). Furthermore, antibiotic-resistant strains determined were also equally sensitive to $\mathrm{HNO}_{2}$. More importantly, $\mathrm{HNO}_{2}$ killed mucoid bacteria (a) in anaerobic biofilms; (b) in vitro in ultrasupernatants of airway secretions derived from explanted CF patient lungs; and (c) in mouse lungs in vivo in a pH-dependent fashion, with no organisms remaining after daily exposure to $\mathrm{HNO}_{2}$ for 16 days. $\mathrm{HNO}_{2}$ at these levels of acidity and $\mathrm{NO}_{2}{ }^{-}$also had no adverse effects on cultured human airway epithelia in vitro. In summary, selective killing by $\mathrm{HNO}_{2}$ may provide novel insights into the important clinical goal of eradicating mucoid $P$. aeruginosa from the CF airways.
\end{abstract}

\section{Introduction}

Pseudomonas aeruginosa is an important pathogen that is most refractory to therapy when it forms biofilms in the airways of cystic fibrosis (CF) patients. CF is caused by mutations in the CF transmembrane conductance regulator (CFTR) gene. Although airway CFTR functions predominantly as an epithelial $\mathrm{Cl}^{-}$channel, it serves to coordinate $\mathrm{Na}^{+}$absorption and $\mathrm{Cl}^{-}$secretion to produce sufficient airway surface liquid (ASL) for normal mucus clearance (1). Without functional CFTR, isotonic hyperabsorption of ASL, driven by enhanced absorption of $\mathrm{Na}^{+}$via the epithelial sodium channel, results in ASL depletion, mucus concentration, and the formation of stagnant mucus plaques (2). Another feature of CF ion transport dysfunction is that the ASL may be acidified $(\mathrm{pH}<6.5)$ due to defective bicarbonate $\left(\mathrm{HCO}_{3}^{-}\right)$ ion transport (3).

Two simultaneous seminal studies have recently indicated that the mucus layer lining the CF airway lumen is anaerobic

Nonstandard abbreviations used: ASL, airway surface liquid; carboxy-PTIO, 2-(4carboxyphenyl)-4,4,5,5-tetramethylimidazoline-1-oxyl-3-oxide; CF, cystic fibrosis; CI, competitive index; LB, Luria-Bertani broth; NAR, nitrate reductase; NIR, nitrite reductase; NOR, NO reductase.

Conflict of interest: A patent has been filed on this technology by the University of Cincinnati naming D.J. Hassett as the sole inventor. He would share in royalties, if any, according to the university's patent policy set forth in university rule no. 3361:10-19-01.

Citation for this article: J. Clin. Invest. 116:436-446 (2006). doi:10.1172/JCI24684. and that robust biofilm formation by $P$. aeruginosa occurs under such conditions $(4,5)$. The anaerobic nature of the CF airway mucus reflects the oxygen-consumptive activities of airway epithelia, $P$. aeruginosa, and other opportunistic pathogens as well as neutrophils that combat infection. As chronic CF lung disease progresses, mucoid, alginate-overproducing strains emerge and become the predominant form (6). Mucoid P. aeruginosa biofilms are inherently resistant to antibiotics (7) and phagocytic neutrophils (8). Although several gene products have been reported to stimulate either a genotypic or phenotypic switch to the mucoid form, the best-characterized mechanism of mucoid conversion in CF isolates is via mutations in mucA, encoding an anti- $\sigma$ factor (9). Without MucA, the extracytoplasmic o factor $\operatorname{AlgT}(\mathrm{U})$ transcribes genes involved in alginate biosynthesis. Mutations in $m u c A$ and mucoid conversion can be triggered in vitro when biofilms are treated with $\mathrm{H}_{2} \mathrm{O}_{2}$ at levels similar to those generated by human neutrophils (10), professional phagocytes that are abundant in the CF airways. Approximately $84 \%$ of mucoid CF isolates $(n=53)$ in the US have been shown to possess mucA mutations (11). In contrast, mucoid mucA mutant bacteria are found in approximately $44 \%$ of the CF isolates from Australia, although the number of patients studied was substantially less than in the US cohort (12).

An important link between mucoidy and anaerobic metabolism by $P$. aeruginosa was identified in a study demonstrating that mucoid organisms were incapable of reversion to their nonmucoid, 


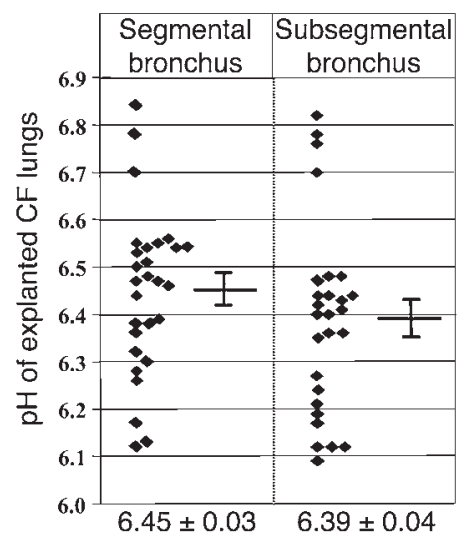

Figure 1

The $\mathrm{pH}$ of $\mathrm{CF}$ airway mucus is slightly acidic. In situ $\mathrm{pH}$ measurements of mucopurulent airway secretions from CF airways were made as described in Methods. Each measurement is presented as an individual data point in the scatter plots. The mean \pm SEM is shown below each panel.

antibiotic- and phagocyte-susceptible counterparts during anaerobic growth (13), results that were confirmed in 2002 by Wyckoff et al. (14). Recently, Worlitzsch and colleagues reported that anaerobic ASL favored production of alginate by $P$. aeruginosa (4). P. aeruginosa is capable of robust anaerobic growth by respiration using nitrate $\left(\mathrm{NO}_{3}{ }^{-}\right)$or nitrite $\left(\mathrm{NO}_{2}^{-}\right)$as terminal electron acceptors (5). $\mathrm{NO}_{3}{ }^{-}$and $\mathrm{NO}_{2}{ }^{-}$are present in CF ASL (15-18) and sputum (19), and $\mathrm{NO}_{3}{ }^{-}$levels have been estimated as high as $600 \mu \mathrm{M}(19)$, concentrations permissive for anaerobic $P$. aeruginosa growth in vitro and in vivo (20). Still, during anaerobic growth, $P$. aeruginosa must control the levels of a toxic intermediate of $\mathrm{NO}_{2}{ }^{-}$reduction, $\mathrm{NO}$, by synthesis of protective NO reductase (NOR) (5). This requirement was demonstrated by the observation that overproduction of $\mathrm{NO}$ by anaerobic $P$. aeruginosa biofilms lacking the $r b l$ quorum sensing circuit caused a metabolic suicide of these bacteria, an event that was prevented by a NO scavenger (21).

$\mathrm{NO}$ is also produced in normal airway epithelia by 3 different NO synthases (NOSs). Neuronal NOS and eNOS isoforms are constitutively expressed. The third isoform (iNOS) is also constitutively expressed in the airways but is inducible and upregulated in response to proinflammatory cytokines and bacterial LPS (22). Specifically, the iNOS2 class of enzymes contributes most effectively to the antimicrobial armament of the airway. However, in chronic CF, iNOS2 activity is significantly reduced (23), and this defect is thought to contribute to the persistence of airway $P$. aeruginosa populations.

Herein we describe a novel approach to killing mucoid $P$. aeruginosa. This is attributable in part to the organism's extremely low nitrite reductase (NIR) and NOR activity, a defect dependent upon mucA mutations. We investigated the mechanism of this effect in in vitro human studies and explored the therapeutic potential of $\mathrm{NO}_{2}{ }^{-}$in both human and mouse safety and mouse in vivo efficacy studies. Treatment of mucoid, mucA mutant bacteria with $\mathrm{NO}_{2}{ }^{-}$at $\mathrm{pH} 6.5$ under anaerobic conditions, similar to conditions within mucopurulent secretions in the airways of CF patients, led to the death of these organisms. Ultimately, this observation may lead to the development of novel therapies for $C F$ patients colonized with mucoid $P$. aeruginosa.

\section{Results}

$C F$ airway luminal secretion $p H$ is slightly acidic. The goal of this study was to test the hypothesis that mucoid $P$. aeruginosa are far more adept at growing during anaerobic respiration than nonmucoid bacteria, which is based on the fact that mucoid bacteria emerge and predominate during the chronic stages of CF airway disease. However, to accurately test this hypothesis, we wanted to assure that our medium $\mathrm{pH}$ was identical to that of the CF airway mucus. Previous in vitro studies suggest that the $\mathrm{pH}$ of the CF ASL is less than 6.5 (3). However, it is conceivable that the $\mathrm{pH}$ of mucopurulent secretions within $\mathrm{CF}$ airways might differ in vivo. Hence, we performed in situ $\mathrm{pH}$ measurements of luminal secretions from freshly explanted lungs removed from 9 different CF patients at the time of transplantation. The $\mathrm{pH}$ of the secretions was slightly lower than what was observed in vitro: $6.45 \pm 0.03$ in segmental airways and somewhat lower in more distal subsegmental bronchi $(6.39 \pm 0.04$; Figure 1$)$. These results guided our selection of $\mathrm{pH} 6.5$ for subsequent experiments.

Mucoid, mucA mutant bacteria are sensitive to acidified $\mathrm{NO}_{2}^{-}$. Based upon the slightly acidic $\mathrm{pH}$ measurements of segmental and subsegmental bronchi from CF transplant patients discussed above, we elected to grow various well-characterized $P$. aeruginosa strains at $\mathrm{pH} 6.5$ under strict anaerobic conditions. Thus, upon anaerobic culture of $P$. aeruginosa at $\mathrm{pH} 6.5$ with $15 \mathrm{mM} \mathrm{NO}_{3}^{-}$(electron acceptor), mucoid $P$. aeruginosa strain FRD1 grew more slowly than nonmucoid strains PAO1 and FRD1/pmucA. Strain FRD1 is the best characterized mucoid, $m u c A$ mutant derived from a $\mathrm{CF}$ patient (24). However, no difference in viability patterns was observed (Figure 2A). Using $15 \mathrm{mM} \mathrm{NO}_{2}{ }^{-}$, however, mucoid FRD1 was killed at a rate of approximately $90 \%$ per day, while nonmucoid strains PAO1 and FRD1/pmucA remained viable over the 4-day incubation (Figure 2B).

After discovering this unique $\mathrm{NO}_{2}^{-}$sensitivity of mucA mutant strain FRD1, we also found that $\mathrm{NO}_{2}{ }^{-}$killed these bacteria more effectively at a lower $\mathrm{pH}$ (Figure 2C), while little or no killing was observed in strain FRD1/pmucA at $\mathrm{pH}$ 6.0-7.5 (Figure 2C).

To test whether $\mathrm{NO}_{2}^{-}$killing of mucoid bacteria occurs in the presence of nonmucoid bacteria, mucoid and nonmucoid $P$. aeruginosa were mixed and treated with $15 \mathrm{mM} \mathrm{NO}_{2}^{-}$anaerobically. Strain FRD1 consistently lost viability at 3 different bacterial test ratios, while nonmucoid FRD1/pmucA maintained viability (Figure 2D).

We next characterized the dose-effect relationship between $\mathrm{NO}_{2}{ }^{-}$ concentration and killing of mucoid bacteria. Figure $2 \mathrm{E}$ shows that $90-95 \%$ of the bacteria were killed by $15 \mathrm{mM} \mathrm{NO}_{2}^{-}$and the $\mathrm{LD}_{50}$ was approximately $3 \mathrm{mM} \mathrm{NO}_{2}{ }^{-}$after 24 hours. The remaining organisms did not develop resistance to $\mathrm{NO}_{2}^{-}$when we extended our study to 12 days (Figure $2 \mathrm{~F}$ ), demonstrating that all organisms were killed during this time period.

Other mucoid, mucA mutant $\mathrm{CF}$ isolates are also sensitive to $\mathrm{NO}_{2}^{-}$. To test whether $\mathrm{NO}_{2}{ }^{-}$sensitivity is a trait of all mucA mutant mucoid CF isolates, the mucA genes of 94 mucoid clinical isolates recovered from a variety of CF clinics in the US and Canada were sequenced. Of 94 strains, 82 harbored mucA mutations, leading to either premature termination of translation (88\%) or a loss of the stop codon (12\%), thereby confirming previous findings (13) that mucA mutations are the major reason for mucoid conversion in CF isolates (Figure 3 and Supplemental Table 1; supplemental material available online with this article; doi:10.1172/JCI24684DS1). The most abundant mutations were 
A
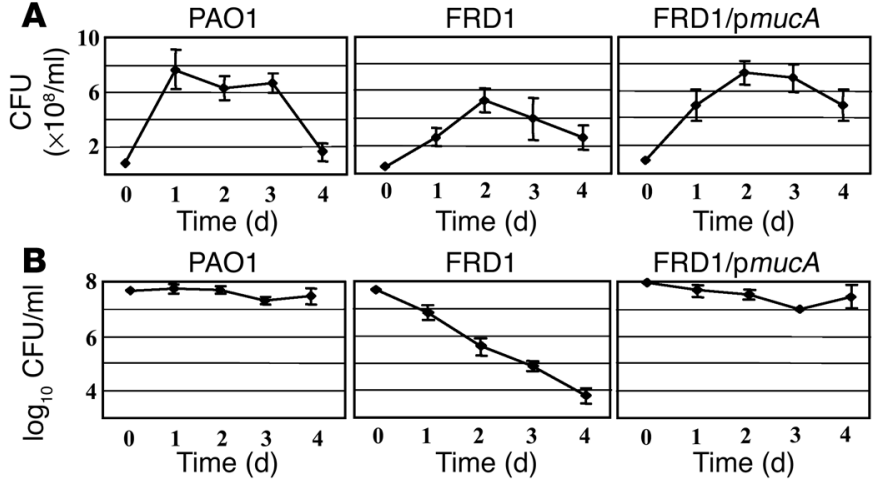

FRD1

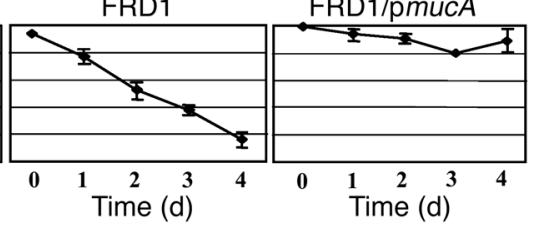

C

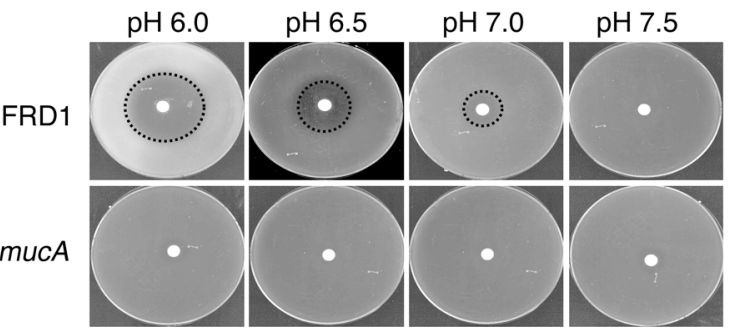

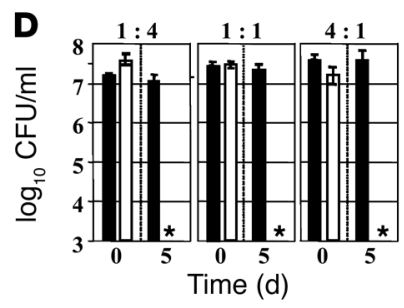

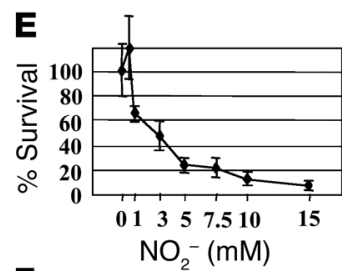

F

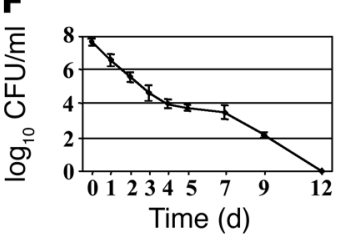

Figure 2

Mucoid $P$. aeruginosa FRD1 is selectively killed by $\mathrm{NO}_{2}^{-}$in a pH-dependent manner. Anaerobic growth of $P$. aeruginosa strains at $\mathrm{pH} 6.5$ using $15 \mathrm{mM} \mathrm{NO}_{3}{ }^{-}$or $\mathrm{NO}_{2}{ }^{-}$as a terminal electron acceptor. Aerobic overnight suspensions of PAO1, FRD1, and FRD1/pmucA were diluted 100-fold for the main anaerobic culture with $\mathrm{NO}_{3}{ }^{-}$(A) or $\mathrm{NO}_{2}{ }^{-}$(B). CFUs were enumerated each day and plotted as linear (A) and logarithmic (B) graphs. (C) $\mathrm{NO}_{2}{ }^{-}$sensitivity versus $\mathrm{pH}$. FRD1 or FRD1/pmucA were seeded onto LB agar buffered at the indicated $\mathrm{pH}$ value. After placing a filter disk containing $10 \mu \mathrm{l}$ of $1 \mathrm{M} \mathrm{NO}_{2}^{-}$, the plates were incubated anaerobically for 48 hours and scanned for viewing the zone of killing. To support anaerobic growth, $15 \mathrm{mM} \mathrm{NO}_{3}{ }^{-}$was included in the media. (D) Mucoid strain FRD1 (gray bars) and nonmucoid FRD1/pmucA (black bars) were incubated together at the indicated ratios (FRD1/pmucA:FRD1) for 5 days in the presence of $15 \mathrm{mM} \mathrm{NO}_{2}^{-}, \mathrm{pH} 6.5$, after which CFUs were determined. ${ }^{*} P<0.001$ versus CFU in the initial inoculum. (E) Dose-response killing of mucoid strain FRD1 by $\mathrm{NO}_{2}^{-}$. Bacteria were suspended in $\mathrm{LB}\left(\mathrm{pH}\right.$ 6.5) with various amounts of $\mathrm{NO}_{2}{ }^{-}$for 24 hours under anaerobic conditions. Survival against $\mathrm{NO}_{2}{ }^{-}$is presented as the percentage of CFU relative to that in initial inoculum. (F) Long-term anaerobic exposure of mucoid strain FRD1 to $15 \mathrm{mM} \mathrm{NO}_{2}{ }^{-}$at pH 6.5. All experiments were performed in triplicate and presented as mean \pm SEM.

single-bp deletions that resulted in a frame shift leading to premature termination of translation at bp 441 (the wild-type mucA gene is $585 \mathrm{bp}$; see Supplemental Table 1 for a detailed breakdown of mucA mutations in each strain). Consistent with the results of Martin et al. (9), approximately $13 \%$ of mucoid isolates had a wild-type mucA allele, indicating the presence of other mechanisms or mutations allowing for mucoid conversion. Upon anaerobic treatment with $15 \mathrm{mM} \mathrm{NO}_{2}{ }^{-}$at $\mathrm{pH} 6.5$, almost all of the mucA mutant mucoid isolates (78 of 82 strains) showed increased susceptibility to $\mathrm{NO}_{2}^{-}$, with $74 \%$ killed by more than 2 logs relative to the mean of the nonmucoid MucA-proficient organisms (Figure 3). Importantly, 4 strains that were deemed antibiotic resistant were still sensitive to anaerobic treatment of acidified $\mathrm{NO}_{2}^{-}$(Figure 3 , arrows). Out of 12, however, 8 mucoid isolates with a wild-type mucA allele were resistant to acidified $\mathrm{NO}_{2}{ }^{-}$. These results suggest that $\mathrm{NO}_{2}{ }^{-}$sensitivity is likely caused by mucA mutations and not by cellular processes associated with alginate overproduction.

In a separate longitudinal study using $P$. aeruginosa strains isolated from 5 different young CF patients, we consistently detected mucoid P. aeruginosa as the patient aged, a hallmark of chronic infection (Table 1). As predicted, initial airway colonization of each tive to killing by $\mathrm{NO}_{2}{ }^{-}$(Table 2). We next tested whether $\mathrm{NO}_{2}{ }^{-}$ also killed $m u c B, m u c D$, and algW mutants of strain PAO1. Other than mucA, the aforementioned genes are the only reported loci that, when inactivated, allow for mucoid conversion in P. aeruginosa (25-27). In contrast to $m u c A$ mutant bacteria, these mutants were not sensitive to $\mathrm{NO}_{2}^{-}$(Table 2). Most critically, 5 nonmucoid revertants of mucoid strains were still sensitive to $\mathrm{HNO}_{2}$ (see Table 2). Therefore, our results suggest that $\mathrm{NO}_{2}{ }^{-}$sensitivity is MucA- and not alginate dependent. Finally, the $\mathrm{LD}_{50}$ of $\mathrm{NO}_{2}{ }^{-}$for sensitive strains was almost identical to that for FRD1 (Figure 2E), suggesting that the rate at which these organisms were killed by $\mathrm{NO}_{2}{ }^{-}$was similar to that of strain FRD1.

$\mathrm{HNO}_{2}$ is required for killing of mucA mutant bacteria; $\mathrm{NO}$ and other $\mathrm{HNO}_{2}$-derived intermediates are responsible. Collectively, our results indicate that the acidic $\mathrm{pH}$ approximately 6.5 of the $\mathrm{CF}$ airway mucus promotes the generation of $\mathrm{NO}_{2}-$ derivative(s) that selectively kill mucA mutant $P$. aeruginosa. Undoubtedly, these derivatives originate from nitrous acid $\left(\mathrm{HNO}_{2}, \mathrm{pK}_{\mathrm{a}}=3.3\right.$, where $\mathrm{pK}_{\mathrm{a}}$ is the negative logarithm of the equilibrium constant $\mathrm{K}_{\mathrm{a}}$ ), whose equilibrium concentration increases with medium acidity. We tested this conjecture by exposing strain FRD1 to 2 different culture conditions with identical $\mathrm{HNO}_{2}$ concentrations of approxi- 


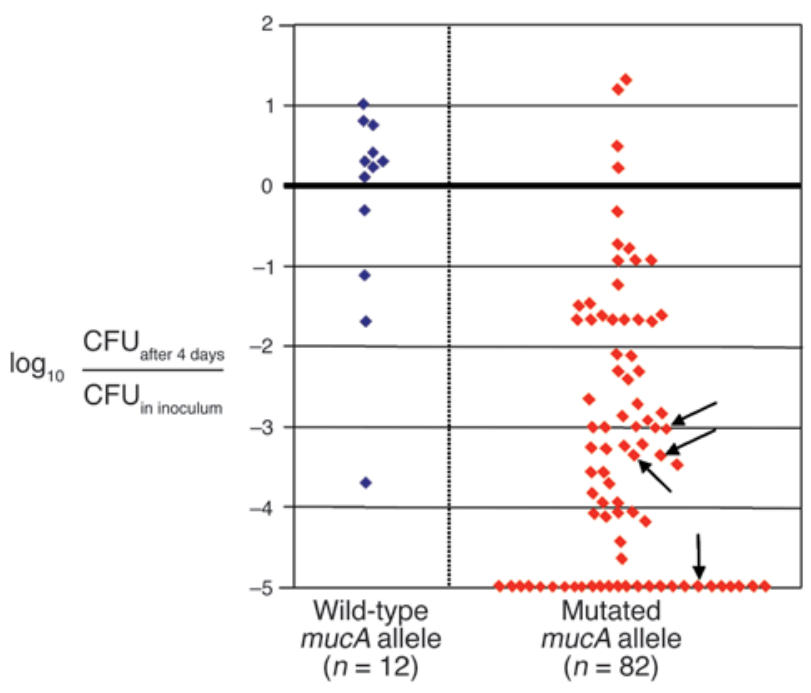

Figure 3

$\mathrm{HNO}_{2}$ sensitivity of 94 different mucoid CF clinical isolates of $P$. aeruginosa. Aerobic starter cultures of each strain were diluted 100 -fold in $\mathrm{LB}$ ( $\mathrm{pH}$ 6.5) supplemented with $15 \mathrm{mM} \mathrm{NO}_{2}^{-}$. The CFU in the inoculum versus that after a 4-day anaerobic incubation were determined. The values for $\log _{10}$ [CFU $\mathrm{Cfter}_{4}$ days $/ \mathrm{CFU}$ inoculum] were calculated and are plotted as the viability index. The mucA gene of each isolate was sequenced, and mucoid strains with wild-type mucA alleles and those harboring mucA mutation were shown at left and right, respectively. Arrows indicate clinical isolates that were found to be highly resistant to amikacin, aztreonam, cefepime, ceftazidime, ciprofloxacin, gentamycin, imipenem, and tobramycin.

mately $10 \mu \mathrm{M}$ (pH 6.5, $15 \mathrm{mM} \mathrm{NO}_{2}^{-}$, and pH 5.5, $1.5 \mathrm{mM} \mathrm{NO}_{2}^{-}$). Under both conditions, equal killing of bacteria was observed, supporting the notion that formation of $\mathrm{HNO}_{2}$ is a prerequisite for killing mucoid $P$. aeruginosa (Figure 4A). Both mucoid FRD1 and nonmucoid FRD1/pmucA maintained viability at these $\mathrm{pH}$ values when no $\mathrm{NO}_{2}^{-}$was added (Figure 4A, left side of each plate).

At such low concentrations, $\mathrm{HNO}_{2}$ is unlikely to directly inflict lethal lesions because it is relatively unreactive and would revert to $\mathrm{NO}_{2}^{-}$upon penetrating bacterial membrane and entering the neutral cytoplasm. However, $\mathrm{HNO}_{2}$ is unstable toward disproportionation that slowly generates $\mathrm{NO}$ and $\mathrm{NO}_{3}{ }^{-}$. Consistent with this chemistry, our results revealed that $\mathrm{NO}$ accumulated upon addition of $\mathrm{NO}_{2}^{-}$to Luria-Bertani broth (LB) at $\mathrm{pH} 6.5$ (Figure 4B). After a rapid rise, NO levels plateau at approximately $490 \mathrm{nM}$, which corresponds to the decomposition of a small fraction of added $\mathrm{NO}_{2}^{-}$and indicates that its decomposition is impeded by accumulating NO. The addition of the stoichiometric NO scavenger, 2-(4-carboxyphenyl)4,4,5,5-tetramethylimidazoline-1-oxyl3-oxide (carboxy-PTIO), temporarily depleted NO, but the NO level was promptly restored following scavenger consumption. This dynamic behavior directly bears on the bactericidal action of acidified $\mathrm{NO}_{2}{ }^{-}$and is explicable by the well-established 2-step $\mathrm{HNO}_{2}$ decomposition mechanism (Supplemental Table 2). In the first reversible step, a pair of NO and $\mathrm{NO}_{2}{ }^{\circ}$ radicals are generated (Equation 1), but this reaction is so strongly shifted to the left that only $3 \mathrm{nM}$ each of $\mathrm{NO}$ and $\mathrm{NO}_{2}{ }^{\bullet}$ are present at equilibrium.

\section{Equation 1}

$$
\mathrm{HNO}_{2}+\mathrm{HNO}_{2} \leftrightarrow \mathrm{N}_{2} \mathrm{O}_{3}+\mathrm{H}_{2} \mathrm{O} \leftrightarrow \mathrm{NO}+\mathrm{NO}_{2}{ }^{+}+\mathrm{H}_{2} \mathrm{O}
$$

However, the second dimerization/hydrolysis step (Equation 2) removes $\mathrm{NO}_{2}{ }^{\circ}$, thus shifting the equilibrium of Equation 1 to the right and leading to accumulation of $\mathrm{NO}$ to a level at which the reverse $\mathrm{NO}+\mathrm{NO}_{2} \cdot$ reaction in Equation 1 outcompetes the $\mathrm{NO}_{2} \cdot$ dimerization/hydrolysis, making further $\mathrm{NO}$ accumulation extremely slow.

\section{Equation 2}

$$
\mathrm{NO}_{2}^{-}+\mathrm{NO}_{2}^{-}+\mathrm{H}_{2} \mathrm{O} \rightarrow \mathrm{NO}_{3}^{-}+\mathrm{NO}_{2}^{-}+2 \mathrm{H}^{+}
$$

This chemistry is amenable to a kinetic analysis by computer simulation (ref. 28 and Supplemental Table 2) revealing that the initial rate of NO accumulation of approximately $4 \mu \mathrm{M} / \mathrm{h}$ decreases by more than 3 orders of magnitude when NO reaches approximately $500 \mathrm{nM}$; notably, identical $\mathrm{NO}$ accumulation profiles are predicted for $15 \mathrm{mM} \mathrm{NO}_{2}^{-}, \mathrm{pH} 6.5$ and $1.5 \mathrm{mM} \mathrm{NO}_{2}^{-}$, $\mathrm{pH} 5.5$, thereby explaining the results in Figure 4A. As observed in Figure 4B, the simulations predict $90 \%$ NO depletion in 25 minutes upon the addition of $200 \mathrm{nM}$ carboxy-PTIO and clearly show that out of the 3 intermediates of $\mathrm{NO}_{2}{ }^{-}$decomposition $\left(\mathrm{HNO}_{2}, \mathrm{NO}_{2}{ }^{\circ}\right.$, and $\left.\mathrm{NO}\right)$, only $\mathrm{NO}$ reacts with carboxy-PTIO. If

\section{Table 1}

Age-dependent emergence of mucA mutant $P$. aeruginosa from 5 different CF patients and sensitivity of each isolate to acidified $\mathrm{NO}_{2}^{-}$

$\begin{array}{cccccc}\text { Patient } & \text { Age (yr) } & \text { Mucoid } & \text { mucA mutation } & \text { Viability index } & \text { Note } \\ \text { A } & 2.8 & \text { NM } & \text { No } & 0.72 & \text { First } P \text {. aeruginosa colonization } \\ & 4.5 & \text { NM } & \text { No } & 0.13 & \\ & 6.0 & \text { M } & \text { Yes, stop at } 441 & -3.1 & \text { First mucoid } P \text {. aeruginosa isolation } \\ \text { B } & 1.2 & \text { NM } & \text { No } & 0.21 & \text { First } P \text {. aeruginosa colonization } \\ & 3.0 & \text { NM } & \text { No } & 1.07 & \\ & 5.3 & \text { M } & \text { No } & -3.14 & \text { First mucoid } P \text {. aeruginosa isolation } \\ & 5.5 & \text { M } & \text { Yes, stop at } 351 & -2.93 & \text { Mucoid } P \text {. aeruginosa isolation } \\ \text { C } & 0.5 & \text { NM } & \text { No } & 1.3 & \text { First } P \text {. aeruginosa colonization } \\ & 2.5 & \text { NM } & \text { No } & 0.15 & \\ & 2.9 & \text { M } & \text { Yes, stop at } 441 & -1.9 & \text { First mucoid } P \text {. aeruginosa isolation } \\ \text { D } & 6.0 & \text { NM } & \text { No } & 0.13 & \text { First } P \text {. aeruginosa colonization } \\ & 7.6 & \text { NM } & \text { No } & 1.13 & \\ & 10.7 & \text { M } & \text { Yes, stop at } 441 & -2.88 & \text { First mucoid } P \text {. aeruginosa isolation } \\ \text { E } & 2.2 & \text { NM } & \text { No } & 1.2 & \text { First } P \text {. aeruginosa colonization } \\ & 5.3 & \text { NM } & \text { No } & 1.09 & \\ & 5.7 & \text { M } & \text { No } & 0.9 & \text { First mucoid } P \text {. aeruginosa isolation }\end{array}$

The mucA genes of 3-4 sequential isolates from each patient were sequenced and viability index of all isolates were determined as described in Figure 3. Age provided is the age at which bacterial samples were isolated. NM, nonmucoid; $M$, mucoid. 
Table 2

Correlation between mucA mutations and $\mathrm{NO}_{2}{ }^{-}$sensitivity

\begin{tabular}{|c|c|c|c|c|}
\hline Strain & Mucoid & mucA mutation & Viability index & $\mathrm{LD}_{50}$ \\
\hline PD0300 (PA01 mucA22) & M & Yes & -2.4 & $4.1( \pm 0.2)$ \\
\hline PA01 mucB:: $\mathrm{Tc}^{r}$ & M & No & 0.45 & $\mathrm{~N} / \mathrm{A}$ \\
\hline 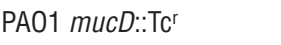 & M & No & 0.39 & N/A \\
\hline PA01 algW::Tcr & M & No & 0.57 & $N / A$ \\
\hline FRD1 & NM & Yes & -3.84 & $2.8( \pm 0.18)$ \\
\hline FRD1 algD::Tn501 & NM & Yes & $<-3.48$ & $2.5( \pm 0.1)$ \\
\hline FRD1 algT(U)::Tn501 & NM & Yes & -3.95 & $2.45( \pm 0.15)$ \\
\hline Clinical isolate 35 & NM & Yes & $<-3.71$ & $3.1( \pm 0.08)$ \\
\hline Clinical isolate 37 & NM & Yes & $<-4.12$ & $2.2( \pm 0.1)$ \\
\hline Clinical isolate 38 & NM & Yes & $<-4.54$ & $2.55( \pm 0.34)$ \\
\hline Clinical isolate 40 & NM & Yes & $<-3.87$ & $2.6( \pm 0.2)$ \\
\hline
\end{tabular}

FRD1 and $P$. aeruginosa clinical isolates $35,37,38$, and 40 are nonmucoid (NM) revertants from the original mucoid $(\mathrm{M})$ isolates (see Supplemental Table 1). Viability index was calculated as described in Figure 3 . The $\mathrm{LD}_{50}$ of $\mathrm{NO}_{2}{ }^{-}$was determined from a graph correlating the percent survival of strains after 24 hours of exposure to acidified $\mathrm{NO}_{2}-$ ranging from $1-5 \mathrm{mM}$ (see Figure $2 \mathrm{E}$ ).

$\mathrm{HNO}_{2}$ reacted, the addition of carboxy-PTIO would cause no change in $\mathrm{NO}$ concentration. If $\mathrm{NO}_{2}{ }^{*}$ were reactive, we would observe a sharp 200-nM increase in the NO concentration upon carboxy-PTIO addition. Thus, carboxy-PTIO is a selective NO scavenger in our system.

This analysis naturally suggests that $\mathrm{NO}$ is involved in the microbicidal action of $\mathrm{HNO}_{2}$. It also allows an experimentally verifiable prediction that carboxy-PTIO should have a strong protective effect when added at millimolar concentrations. As shown in Figure 4C, such protection is indeed observed. The computer modeling analysis shows that, under the conditions in Figure 4C, carboxy-PTIO will persist in solution for several weeks, keeping NO concentrations at picomolar levels. Similarly protective effects were observed with another NO scavenger, deoxyhemoglobin (Figure 4C and ref. 29). These experiments therefore establish that NO was at least potentially 1 direct or indirect contributor to the bactericidal activity of acidified $\mathrm{NO}_{2}{ }^{-}$. This conclusion is strongly supported by the observation that strain FRD1, but not FRD1/pmucA, was killed when an $\mathrm{NO}$ /argon gas mixture was bubbled into the bacterial suspension (Figure 4D); a 380-nM solution concentration of NO maintained in this experiment was comparable to that generated by $15 \mathrm{mM} \mathrm{NO}_{2}^{-}$at $\mathrm{pH} 6.5$ (Figure 4B). In contrast, both strains maintained viability when treated with argon gas.

Although a link between NO depletion and the decrease of bactericidal activity of acidified $\mathrm{NO}_{2}{ }^{-}$clearly exists, it is premature to conclude that $\mathrm{NO}$ is per se the toxic agent in this system or the only toxic agent. NO depletion, whether through the action of exogenous carboxy-PTIO or endogenous NOR activity, may inhibit several downstream reactions by which $\mathrm{HNO}_{2}$ may kill mucoid $P$. aeruginosa. These reactions alter the reaction dynamics modeled in buffer alone and may ultimately prove relevant to the observed bactericidal effect of $\mathrm{HNO}_{2}$. For example, high $\mathrm{NO}$ levels promote formation of a strong nitrosating intermediate, $\mathrm{N}_{2} \mathrm{O}_{3}$ in Equation 1, which can cause "nitrosative stress" by modifying the function of proteins (30). Additionally, NO can react with iron and sulfur species in bacteria to form bioactive $S$-nitrosothiols (31) that may be potent in killing mucoid $P$. aeruginosa, an intriguing possibility given that $S$-nitrosothiol levels are low in the CF airway.
Although we strived for strictly anaerobic conditions, even remotely low levels of $\mathrm{O}_{2}$ could be problematic because of the attendant generation of $\mathrm{O}_{2}^{-}$, which combines with $\mathrm{NO}$ to form peroxynitrite $\left(\mathrm{ONOO}^{-}\right)$, an extremely bactericidal species $(32,33)$. We used a $\operatorname{sod} A \operatorname{sod} B$ mutant, devoid of iron- and manganese-cofactored superoxide dismutase. As such, it is extremely sensitive to even endogenously generated $\mathrm{O}_{2}^{-}$(34). Were trace oxygen to be reduced to $\mathrm{O}_{2}^{-}$in the $\operatorname{sodAsodB}$ mutant in the presence of $\mathrm{NO}$, then $\mathrm{ONOO}^{-}$would form and kill the $\operatorname{sodAsodB}$ mutant much more rapidly than was observed in wild-type organisms. Figure 4E shows that the $\operatorname{sod} A \operatorname{sod} B$ mutant of strain PAO1 was not sensitive to $\mathrm{HNO}_{2}$ under anaerobic conditions. In contrast and as expected, under aerobic conditions, the $\operatorname{sod} A \operatorname{sod} B$ mutant was more sensitive to $\mathrm{HNO}_{2}$ (Figure 4E, compare lines shown with diamonds). These results indicate that $\mathrm{ONOO}^{-}$is not formed in our anaerobic cultures and that bacterial killing is not due to this species.

Mucoid mucA mutant bacteria harbor low anaerobic NOR and NIR activity. Our next goal was to define the molecular basis of $\mathrm{HNO}_{2}$ sensitivity of mucoid mucA mutant bacteria. We first measured the activity of enzymes involved in $P$. aeruginosa anaerobic respiration, including $\mathrm{NO}_{3}{ }^{-}$reductase (NAR), NIR, and NOR (Figure 5A). Strain FRD1 possessed approximately 3.7 -fold greater NAR activity compared with nonmucoid FRD1/pmucA and PAO1. However, strain FRD1 possessed only $4 \%$ and approximately $20 \%$ the NIR and NOR activity, respectively, of strain PAO1 (Figure 5A). Interestingly, FRD1/ pmucA possessed approximately 2 -fold higher $\mathrm{NO}$ consuming activity compared with strain PAO1 (Figure 5A), suggesting a positive correlation of NOR activity with the presence of multiple copies of wild-type MucA. The reduced NOR activity in strain FRD1 explains in part the very limited capacity for removal of NO by this organism and, hence, its greater sensitivity to purified NO. The lack of NIR activity in strain FRD1 explained the failure of $\mathrm{NO}_{2}^{-}$to support anaerobic growth of this strain. In addition, the low NIR activity in strain FRD1 led to the constancy of $\mathrm{HNO}_{2}$ levels in the culture medium and the attendant increase in $\mathrm{NO}$ levels compared with strains that metabolize $\mathrm{NO}_{2}{ }^{-}$. Strikingly, there was no significant loss of $\mathrm{NO}_{2}^{-}$from the culture medium after 4 days at $\mathrm{pH} 6.5$, suggesting that there was no biological reduction of $\mathrm{NO}_{2}{ }^{-}$in strain FRD1 and 16 different mucoid, mucA mutant CF isolates assessed for $\mathrm{NO}_{2}{ }^{-}$sensitivity (Supplemental Table 1) and remaining $\mathrm{NO}_{2}^{-}$levels (Figure 5B). Moreover, these data also demonstrate that $\mathrm{NO}$ formed from $\mathrm{HNO}_{2}$ at this $\mathrm{pH}$ and $\mathrm{NO}_{2}^{-}$concentration in the presence of mucA mutant organisms was virtually all recycled to $\mathrm{NO}_{2}^{-}$, supporting a mechanism for NIR-deficient mutant bacteria killing that involves $\mathrm{NO}$ oxidation and formation of $\mathrm{NO}^{+}$equivalents. These data confirm the lack of respiratory NIR activity in mucoid, mucA mutant $P$. aeruginosa (Figure 5B). In contrast, supernatants of wild-type strain PAO1 and FRD1/pmucA had little or no media $\mathrm{NO}_{2}{ }^{-}$remaining (Figure $5 \mathrm{~B}$ ).

Finally, because NOR activity was significantly reduced in mucoid bacteria, we postulated that mucoid organisms completely devoid of NOR activity would be more sensitive to $\mathrm{HNO}_{2}$. Figure 5C demonstrates that a nor CB mutant of strain FRD1 was approximately 10 -fold more sensitive to acidified $\mathrm{NO}_{2}^{-}$than were wild-type organisms. 
A

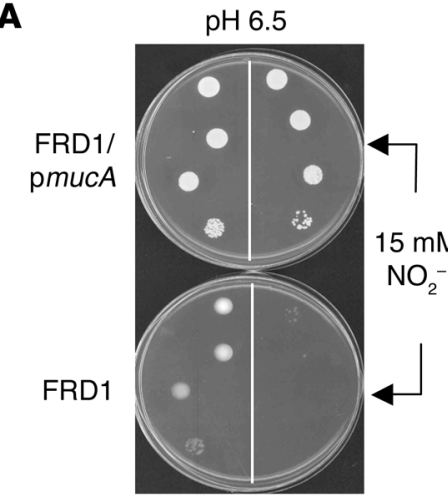

C

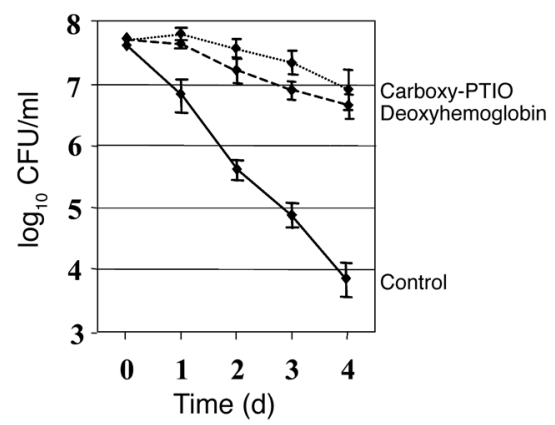

$\mathrm{pH} 5.5$

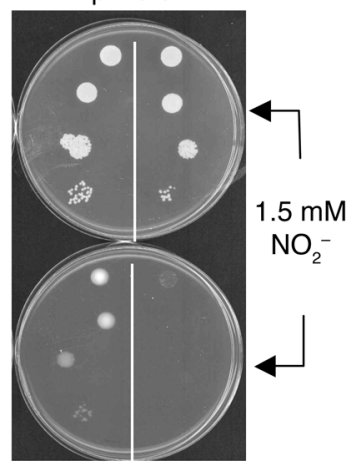

B

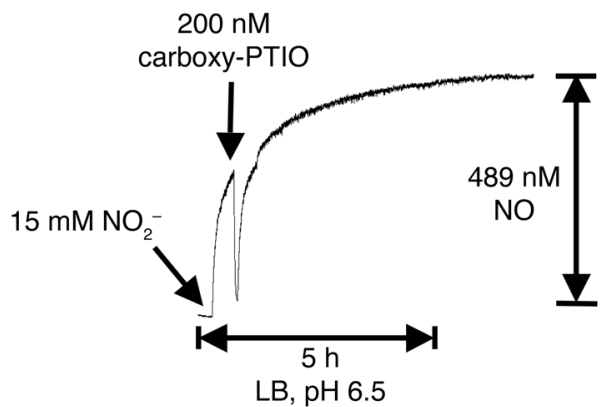

D

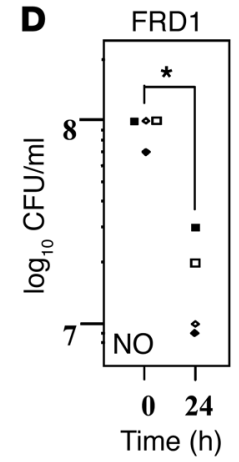

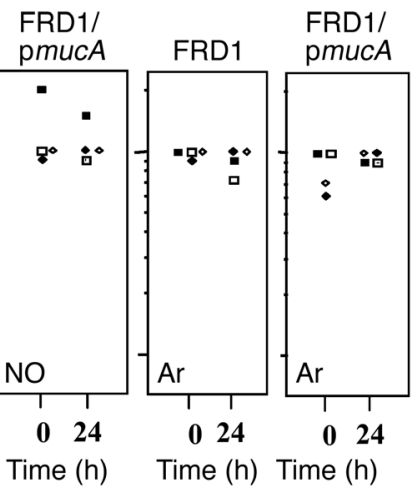

$\mathbf{E}$

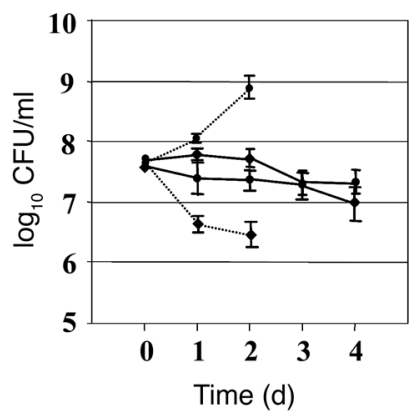

Figure 4

NO is involved in killing of mucoid mucA mutant bacteria. (A) Anaerobic sensitivity of $P$. aeruginosa under conditions allowing for the formation of identical NO levels. Bacteria were incubated anaerobically for 4 days with or without $15 \mathrm{mM}$ and $1.5 \mathrm{mM} \mathrm{NO}_{2}^{-}$at pH 6.5 and 5.5 , respectively. To enumerate viable cells, $10 \mu \mathrm{l}$ of serial dilutions were spotted on LB agar plates and incubated at $37^{\circ} \mathrm{C}$ for 15 hours. The left and right side of each plate represent control and $\mathrm{NO}_{2}^{-}$-exposed bacteria. (B) NO levels generated by $15 \mathrm{mM} \mathrm{NO}_{2}^{-}(\mathrm{pH} 6.5)$ over time. Carboxy-PTIO (200 nM) was added, and the stoichiometric decrease in NO signal is shown. The coefficient of determination $\left(r^{2}\right)$ between NO concentration and electric current $(\mathrm{pA})$ was 0.9997 . (C) Effects of $\mathrm{NO}$ scavengers on protection of FRD1 from acidified $\mathrm{NO}_{2}{ }^{-}$. Carboxy-PTIO (5 mM) or deoxyhemoglobin $(0.5 \mathrm{mM})$ was added in the initial media ( $\left.\mathrm{LB}, \mathrm{pH} 6.5,15 \mathrm{mM} \mathrm{NO}_{2}^{-}\right)$. (D) Toxicity of NO toward FRD1 and FRD1/pmucA in LB at pH 6.5. NO (333 parts per million) balanced with argon was continuously bubbled for 24 hours anaerobically and viable bacteria were subsequently enumerated. Results of 4 experiments are shown. In NO-treated FRD1, differences in CFU between 2 time points were statistically significant $\left({ }^{\star} P<0.01\right)$. (E) $P$. aeruginosa PAO1 (circles) and isogenic sodAsodB double mutants (diamonds) were grown in LB, $\mathrm{pH} 6.5$, containing $15 \mathrm{mM} \mathrm{NO}_{2}-$ under aerobic (2 days, dotted lines) and anaerobic (4 days, solid lines) conditions. CFUs were measured daily and plotted in logarithmic scale. For aerobic samples, strains were grown with vigorous shaking (300 rpm).

$\mathrm{HNO}_{2}$ kills mucoid $P$. aeruginosa in in vitro anaerobic biofilms and fresh sputum isolates from CF patients. To explore the potential clinical application of $\mathrm{HNO}_{2}$ in the treatment of mucoid P. aeruginosa infections in chronic CF patients, we first tested the effect of $\mathrm{NO}_{2}^{-}$on the viability of biofilm bacteria. Anaerobic biofilms of strains FRD1 and FRD1/pmucA were grown for 1 day in media containing $\mathrm{NO}_{3}{ }^{-}$, which supports anaerobic respiration. Since mucoid strain FRD1 lacks a flagellum (35), a surface appendage that is critical for P. aeruginosa biofilm initiation (36), strain FRD1 formed much weaker biofilms than those of flagellated FRD1/ pmucA (Figure 6, compare A and B). When the FRD1 biofilm was treated with $\mathrm{NO}_{2}{ }^{-}$at $\mathrm{pH} 7.5$ for 2 days, no difference in biofilm structure and cell viability was observed relative to control biofilms. In contrast, nearly complete death of biofilm organisms was observed after a 2-day incubation with $\mathrm{NO}_{2}{ }^{-}$at $\mathrm{pH} 6.5$ (Figure 6A, top right). In biofilms of FRD1/pmucA, however, resistance to acidified $\mathrm{NO}_{2}{ }^{-}$was clearly evident (Figure $6 \mathrm{~B}$ ).

We next monitored the effect of $\mathrm{HNO}_{2}$ on the killing of sputum isolates from CF patients. Sputum isolates CF $1,-2,-3$, and -4 harbored nearly $100 \%$ mucoid mucA mutant bacteria, while the
CF5 isolate harbored only nonmucoid MucA-proficient P. aeruginosa (Figure 6C). To minimize loss of the properties acquired in vivo, these isolates were passed only once in L-broth and immediately assayed for anaerobic $\mathrm{NO}_{2}^{-}$sensitivity. When these isolates were exposed to $15 \mathrm{mM} \mathrm{NO}_{2}^{-}$at $\mathrm{pH} 6.5$ under anaerobic conditions for 1 day, a sharp decrease in viability was observed in the mucoid mucA mutant isolates. Again, the inherent utility of these isolates was that they were freshly isolated from CF patients and were not from long-term frozen stocks derived from CF patients. These results clearly indicate that high levels of $\mathrm{HNO}_{2}$ selectively kill mucoid mucA mutant $P$. aeruginosa.

$\mathrm{HNO}_{2}$ kills mucoid $P$. aeruginosa in a sterile ultrasupernatant derived from explanted CF lungs and in mouse airways. Next, we determined whether mucoid strain FRD1 could be killed by $\mathrm{HNO}_{2}$ in sterile ultrasupernatants ( $\mathrm{pH}$ 6.24) of $\mathrm{CF}$ airway secretions derived from explanted CF lungs. This reagent arguably represents the best medium to investigate $P$. aeruginosa in the context of bacterial growth and the effects of $\mathrm{HNO}_{2}$ ex vivo. Figure $7 \mathrm{~A}$ shows that mucoid bacteria were actually killed faster by $\mathrm{HNO}_{2}$ in the $\mathrm{CF}$ ultrasupernatants than in L-broth (Figure 2B). 
A
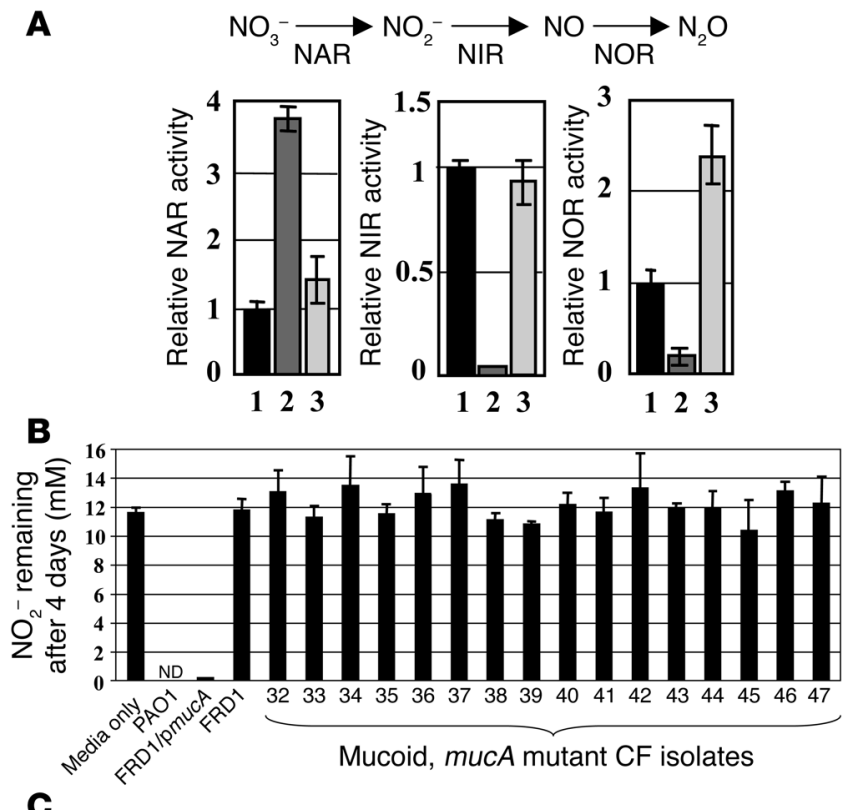

C

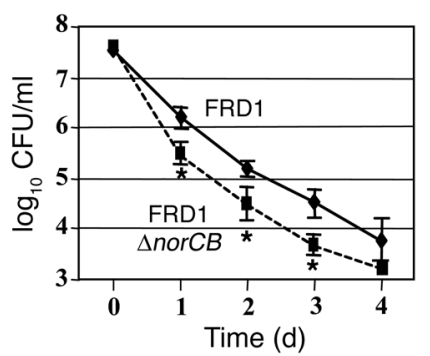

Next, we measured $\mathrm{NO}$ levels generated from $\mathrm{HNO}_{2}$ disproportionation in ASL collected from primary CF airway epithelia. Figure 7B indicates that $\mathrm{NO}$ was produced in CF ASL at levels even greater $(562 \mathrm{nM})$ than those generated in $\mathrm{LB}$ at $\mathrm{pH} 6.5$ (489 nM, Figure 4B). The higher levels of NO produced upon addition of $\mathrm{NO}_{2}{ }^{-}$in this milieu were likely due to the lower $\mathrm{pH}$ of the sample (6.43 versus 6.5).

We then determined the efficacy of $\mathrm{HNO}_{2}$ to kill strain FRD1 in a $P$. aeruginosa chronic lung infection model. Currently, there is no animal model for the anaerobic biofilm mode of CF airway disease or a CF animal that acquires spontaneous $P$. aeruginosa infections. However, CD1 mice inoculated with agarose beads impregnated with bacteria have been useful for studying chronic lung infection by $P$. aeruginosa (37). Consistent with our in vitro results, mucoid FRD1, but not nonmucoid FRD1/pmucA, were decreased more than 2 logs at $\mathrm{pH} 6.5$ and more than 3 logs at $\mathrm{pH} 5.5$ by $\mathrm{HNO}_{2}{ }^{-}$in vivo (Figure $7 \mathrm{C}$ ). Because $\mathrm{NO}$ concentrations derived from acidified $\mathrm{NO}_{2}{ }^{-}$are 10 -fold greater with a reduction of $1 \mathrm{pH}$ unit, our results are consistent with classical $\mathrm{NO}_{2}{ }^{-}$reduction chemistry. Furthermore, organisms that were recovered from the mouse airways after $\mathrm{NO}_{2}{ }^{-}$exposure were still sensitive to $\mathrm{NO}_{2}{ }^{-}$in vitro (data not shown), although these results do not clearly indicate that NO itself within the bacterial cytoplasm is the toxic species.

We also addressed whether long-term treatment with $\mathrm{HNO}_{2}$ produced progressively decreasing airway titers of mucoid, $\mathrm{mucA}$ mutant bacteria. $\mathrm{NO}_{2}{ }^{-}$was instilled on a daily basis in mice infected with mucoid organisms for a period of 16 days. Figure 7D

\section{Figure 5}

Significantly reduced NIR and NOR activities in mucA mutant $P$. aeruginosa account for the sensitivity to $\mathrm{HNO}_{2}$. (A) Relative activities of NAR, NIR, and NOR in FRD1 (lane 2) and FRD1/pmucA (lane 3), normalized to that of the well-characterized laboratory strain PAO1 (lane 1). Each assay was performed in triplicate, and the mean \pm SEM is presented. A schematic diagram of the $P$. aeruginosa anaerobic respiration pathway is shown. Bacteria were grown in LB (pH 6.5) containing $100 \mathrm{mM} \mathrm{NO}_{3}^{-}$for 15 hours under anaerobic conditions. (B) $P$. aeruginosa strains were incubated anaerobically in LB containing $15 \mathrm{mM} \mathrm{NO}_{2}^{-}, \mathrm{pH}$ 6.5. After 4 days at $37^{\circ} \mathrm{C}, \mathrm{NO}_{2}{ }^{-}$levels were measured in triplicate. All other mucA mutant clinical isolates were among those described in Supplemental Table 1. For the media-only control, no bacteria were used. ND, not detected. (C) Anaerobic sensitivity of FRD1 and FRD1 norCB mutant exposed to $\mathrm{NO}_{2}^{-}$at $\mathrm{pH}$ 6.5. Experimental conditions were identical to those used in Figure 2B. $\Delta$, deletion of a specific gene. ${ }^{*} P<0.01$ versus FRD1.

shows that there was no bacteria detected in mice treated for 16 days with $\mathrm{HNO}_{2}$, while buffer control mice still harbored nearly $10^{4}$ mucoid organisms per lung.

To address the possibility that acidified $\mathrm{HNO}_{2}$ can kill mucoid $m u c A$ mutant bacteria in the presence of nonmucoid bacteria in vivo (similar to the results obtained in vitro in Figure 2D), competitive index (CI) experiments were performed. Figure 7E demonstrates that the $\mathrm{CI}$ was only approximately 0.2 for mucoid, mucA mutant strain FRD1 relative to its complemented strain, FRD1/ $\mathrm{p} m u c A$, which was approximately 1.0.

$\mathrm{NO}_{2}{ }^{-}$does not elicit adverse effects on airway epithelia in vitro. The clinical utility of $\mathrm{NO}_{2}{ }^{-}$as a treatment would be diminished if it exerted significant toxic or adverse effects on airway epithelia. Therefore, we tested the effect of $\mathrm{NO}_{2}{ }^{-}$on cell viability and function of cultured airway epithelia. Furthermore, since $\mathrm{NO}_{2}{ }^{-}$ may elicit a proinflammatory response that would be undesirable in the CF airways, and NO has been reported to increase IL-8 gene transcription in a lung epithelial cell line (38), we also tested whether $\mathrm{NO}_{2}{ }^{-}$induces IL-8 release from cultured airway epithelia. Aerosolization, a potential therapeutic delivery route for $\mathrm{NO}_{2}{ }^{-}$to the $\mathrm{CF}$ airways, would deliver it in small volumes on the epithelial surface. To mimic this situation in vitro, we added a low volume $(2 \mu \mathrm{l})$ of test solution containing various concentrations of $\mathrm{NO}_{2}^{-}$to the apical surface of $\mathrm{CF}$ airway epithelia at $\mathrm{pH}$ 6.5. Exposure to concentrations as high as 20 times the dose required to kill mucoid mucA mutant $P$. aeruginosa exerted no cytotoxicity toward CF airway epithelia after 24 hours, as determined by lactate dehydrogenase release (Figure 8A). We performed such experiments because aerosol exposure of any effective agent, regardless of treatment, requires that significantly higher concentrations (about 25 -fold) of stock solution be used so that appropriate doses are administered efficiently to the areas of interest.

In CF culture preparations mounted in Ussing chambers, basal transepithelial short circuit current $\left(\mathrm{I}_{\mathrm{sc}}\right)$ was not affected by $\mathrm{NO}_{2}{ }^{-}$exposure (Figure $8 \mathrm{~B}$ ). Further, $15 \mathrm{mM} \mathrm{NO}_{2}{ }^{-}$failed to affect amiloride-sensitive $\mathrm{I}_{\mathrm{sc}}$ (control, $15.4 \pm 1.4 \mu \mathrm{A} / \mathrm{cm}^{2}$; treated, $15.7 \pm 1.7 \mu \mathrm{A} / \mathrm{cm}^{2} ; P=0.92$ ) and UTP-activated $\mathrm{I}_{\mathrm{sc}}$ (control, $17.7 \pm 3.0 \mu \mathrm{A} / \mathrm{cm}^{2}$; treated, $18.1 \pm 3.3 \mu \mathrm{A} / \mathrm{cm}^{2} ; P=0.92$ ). Consistent with these data, $15 \mathrm{mM} \mathrm{NO}_{2}{ }^{-}$did not alter transepithelial water flux $\left(\mathrm{J}_{\mathrm{v}}\right)$ in the same cultures (Figure $8 \mathrm{C}$ ) or trigger IL-8 release over 24 hours in CF epithelia (Figure 8D). Finally, we performed preliminary studies of the durability of $\mathrm{NO}_{2}{ }^{-}$on $\mathrm{CF}$ 
A

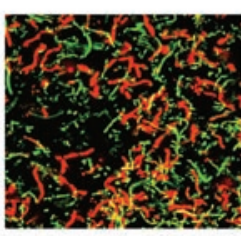

1-day-old anaerobic FRD1 biofilm

$\mathbf{B}$

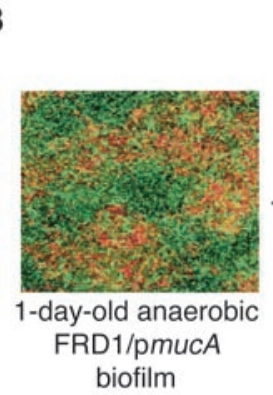

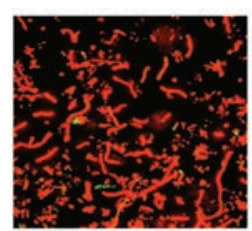

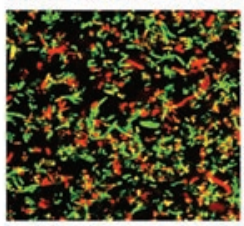

LB, $\mathrm{pH} 7.5$

$15 \mathrm{mM} \mathrm{NO}_{2}$

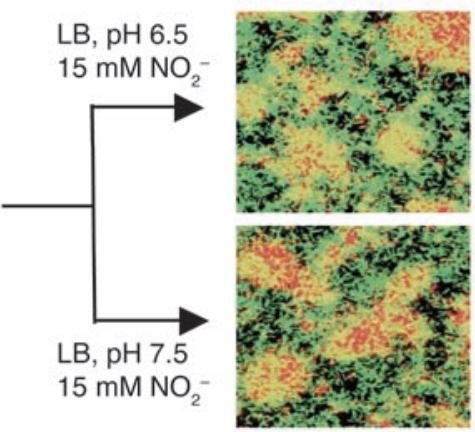

C

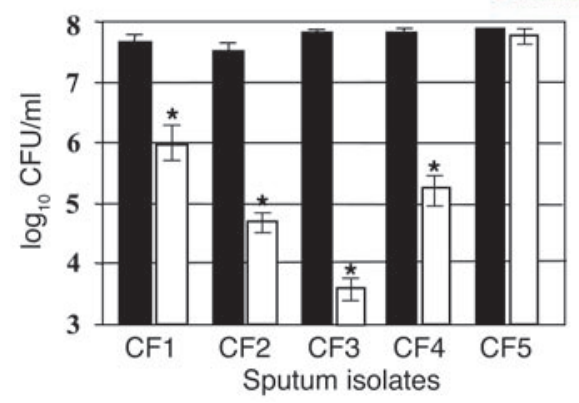

airway surfaces. We found that the half life of $\mathrm{NO}_{2}{ }^{-}$was approximately 5 hours (Figure $8 \mathrm{E}$ ), indicating that $\mathrm{NO}_{2}{ }^{-}$is not immediately removed from the luminal side of $\mathrm{CF}$ airway epithelia.

\section{Discussion}

A hallmark of $\mathrm{CF}$ airway disease is the emergence of alginate-overproducing $P$. aeruginosa, bacteria that have genotypically and/or phenotypically changed from a nonmucoid to mucoid forms and are highly resistant to host defenses (8) and antimicrobial therapy (7). Clinically, the appearance of this organism is correlated with a marked reduction in lung function and nutritional status (39). One major mechanism for $P$. aeruginosa mucoid conversion in CF isolates involves mutations in the mucA gene (9). The only other known genes that are involved in mucoid conversion include $m u c B$ $(\operatorname{alg} N)(27), m u c D(25)$, and $\operatorname{alg} W(25)$, but these mutations are not common in clinical isolates.

In this study, we believe that we have discovered the Achilles' heel of the formidable mucoid form of $P$. aeruginosa, which could lead to improved treatment for $\mathrm{CF}$ airway disease. Under conditions that mimicked the $\mathrm{CF}$ airway mucus, $\mathrm{HNO}_{2}$ was transformed into toxic species that specifically and negatively affected viability of mucoid $P$. aeruginosa. Strikingly, mucA mutant bacteria were very sensitive to species derived from $\mathrm{HNO}_{2}$, which was due at least in part to the inherently low NIR and NOR activ-

\section{Figure 6}

Effect of $\mathrm{HNO}_{2}$ on killing $P$. aeruginosa in biofilms and fresh sputum isolates. (A) Confocal laser microscopic analysis of anaerobic FRD1 biofilms. Live cells are stained with syto-9 (green), and dead cells are stained with propidium iodide (red). Top ( $x-y$ plane) views are projected from a stack of 125 images taken at $0.4-\mu \mathrm{m}$ intervals for a total of $50 \mu \mathrm{m}$. Before staining, 1-day-old anaerobic FRD1 biofilms were treated anaerobically with $15 \mathrm{mM} \mathrm{NO}_{2}{ }^{-}$at $\mathrm{pH} 6.5$ and 7.5 for 2 days. (B) Biofilms were grown as in A using FRD1/pmucA. (C) Toxicity of $15 \mathrm{mM} \mathrm{NO}_{2}{ }^{-}(\mathrm{pH} \mathrm{6.5)}$ toward $P$. aeruginosa sputum isolates. Viable cells in the initial inoculum (black bars) and after a 24-hour anaerobic incubation (white bars) are presented in logarithmic scale. CF1-CF4 are mucoid mucA mutants, and CF5 is nonmuocid and possesses a wild-type mucA gene. Each strain was tested in triplicate and the mean \pm SEM is presented. ${ }^{*} P<0.05$.

ity in these strains. In fact, recent work by Firoved et al. (40) has shown that mucA mutant bacteria have a markedly reduced capacity to remove the NO generated even aerobically from $S$ nitrosoglutathione. This is consistent with our results, which indicated that $\mathrm{NO}$ levels accumulate and remain for greater than 24 hours. Since MucA is an inner membrane-spanning protein and catalytic activities of NIR and NOR reside in the periplasmic space, we speculate that the periplasmic portion of MucA plays a crucial role in orchestrating the biological function of these periplasmic enzymes; indeed, virtually all of the critical mutations in the mucA gene predict defects in the periplasmic localization of MucA. Studies to define a structural relationship between MucA and potential periplasmic proteins are currently underway. $\mathrm{HNO}_{2}$ derivatives can damage DNA (41) and modify protein micromoieties including Fe-S clusters (42), tyrosine residues (43), heme (44), and sulfhydryl groups (45). These mechanisms may be involved in the adverse effects on the overall biology of mucoid, mucA mutant organisms.

Our mucA sequencing data from 94 different strains from 5 $\mathrm{CF}$ clinics confirm the previous findings of Martin et al. (9) that mucoid conversion is mainly caused ( $87 \%$ frequency) by muc $\mathrm{A}$ mutations (Supplemental Table 1). However, variations exist in the mechanisms by which $P$. aeruginosa undergoes mucoid conversion $(9,12)$, and mucoid organisms that have intact mucA alleles are being detected, particularly in Europe. The data presented in this study indicate that only mucA mutant bacteria are susceptible to $\mathrm{HNO}_{2}$.

Airway epithelial expression of iNOS does not differ between young CF patients and normal children (23). However, as CF patients age, expression of iNOS is significantly reduced in CF patients (23). This reduced expression of iNOS in chronic CF is associated with the emergence of mucoid mucA mutant subpopulations. Currently, however, it is unclear whether conversion to the mucoid form, which has limited capacity for NO removal, is facilitated by the abnormally low NO or S-nitrosothiol levels in the airways of older CF subjects (15).

Our data suggest that $15 \mathrm{mM} \mathrm{NO}_{2}{ }^{-}$kills mucA mutant $P$. aeruginosa in $\mathrm{CF}$ airways at $\mathrm{pH} 6.5$. The NO chemistry of bacteria and the $\mathrm{CF}$ airways is complex, and several downstream mechanisms could account for the effect of $\mathrm{HNO}_{2}$ on mucoid $P$ aeruginosa. Our data suggest that NO itself, whether directly or as a precursor to iron-nitrosyl species, may be involved in the antimicrobial effect. Of note, there is evidence that airway acid stress characterizes a variety of pulmonary disorders (46), and our 

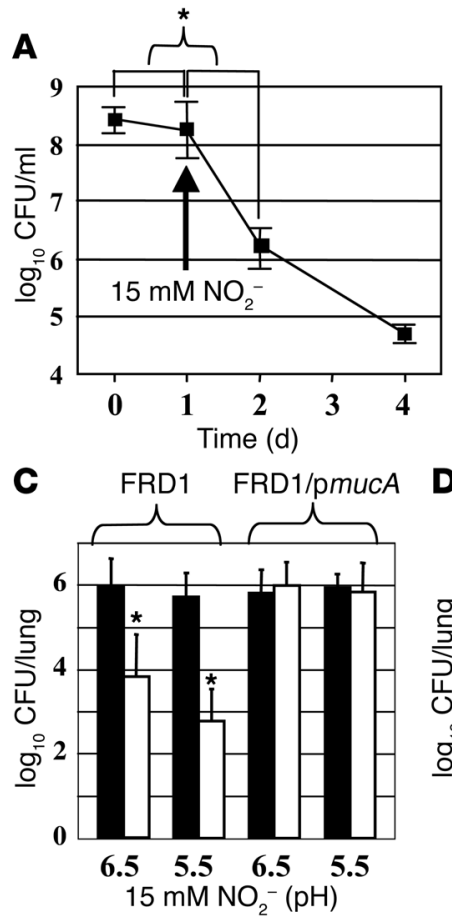

$D$

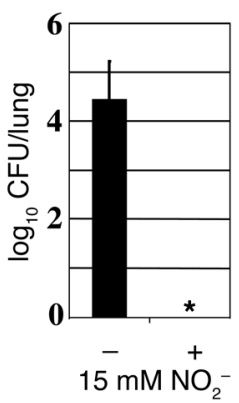

B
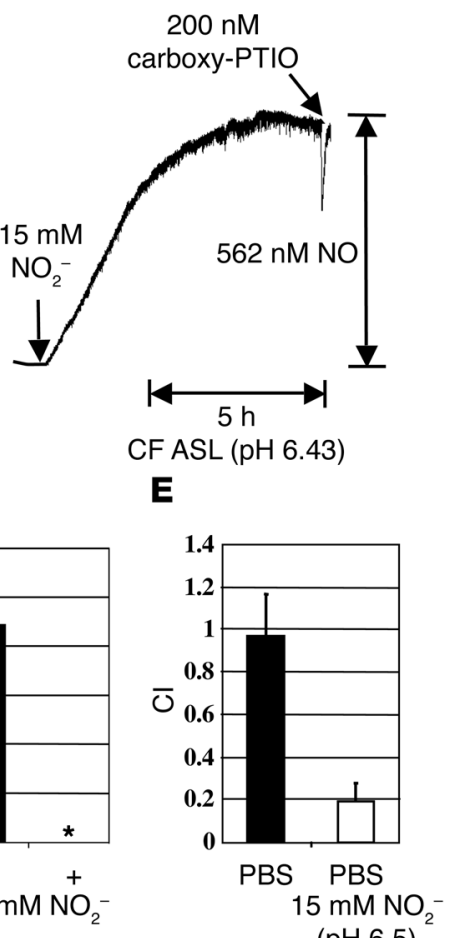

Figure 7

Applications of $\mathrm{HNO}_{2}$-mediated killing of mucoid $P$. aeruginosa to clinical specimens. (A) Killing of FRD1 by $\mathrm{NO}_{2}{ }^{-}$in sterile ultrasupernatants of $\mathrm{CF}$ airway secretions derived from explanted CF lungs. Bacteria were incubated anaerobically for 24 hours, and $15 \mathrm{mM} \mathrm{NO}_{2}^{-}$was added. CFUs were determined $(n=3)$ and plotted as the $\mathrm{X} \pm$ SEM versus time. ${ }^{*} P<0.01$ versus CFU decrease before adding $\mathrm{NO}_{2}{ }^{-}$. (B) NO generation in CF ASL by $15 \mathrm{mM} \mathrm{NO}_{2}{ }^{-}$. Except for the media and $\mathrm{pH}$, experimental conditions were identical to those used in Figure $4 \mathrm{~B}$. (C) Effects of $\mathrm{NO}_{2}{ }^{-}$on killing of FRD1 and FRD1/pmucA in mouse lungs. CD1 mice were infected with FRD1 or FRD1/pmucA as described in Methods. Infected mice were treated with buffer (black bars) and buffered $\mathrm{NO}_{2}{ }^{-}$(white bars) daily, and viable bacteria from the lung homogenates were enumerated. $n=8$ per group. ${ }^{*} P<0.01$ versus buffer alone. (D) Effects of long-term $\mathrm{NO}_{2}{ }^{-}$treatment on killing of FRD1 in mouse lungs. Another group of FRD1-infected mice were treated daily with buffer $(-, 50 \mathrm{mM}$ sodium phosphate, $\mathrm{pH} 6.5)$ or buffer with $15 \mathrm{mM}$ $\mathrm{NO}_{2}{ }^{-}(+)$for 16 days ( $n=8$ per group). Organisms surviving treatment with buffer and $\mathrm{NO}_{2}{ }^{-}$were shown in logarithmic scale. ${ }^{*} P<0.01$ versus buffer alone. (E) $\mathrm{Cl}$ experiments with $10^{6}$ FRD1 and FRD1/pmucA intratracheally instilled into CD1 mouse airways and incubated for 6 days prior to harvesting of mouse lungs and enumeration of CFUs after homogenization. results are consistent with those of Hunt et al. (47), which suggest that delivery of concentrated $\mathrm{NO}_{2}^{-}$to airway regions with low $\mathrm{pH}$ likely serves to generate $\mathrm{NO}$ and $S$-nitrosothiols. Indeed, $\mathrm{NO}$ generated in animal studies of inhaled $\mathrm{NO}_{2}^{-}$may arise from $\mathrm{HNO}_{2}$ formation (18). Inhaled $\mathrm{NO}_{2}{ }^{-}$has appeal as a $\mathrm{CF}$ therapy because it may (a) provide sustained NO release, (b) exploit the low $\mathrm{pH}$ of the $\mathrm{CF}$ airway epithelial mucus layer, (c) selectively inhibit growth of mucoid, mucA mutant $P$. aeruginosa when protonated to form $\mathrm{HNO}_{2}$, and (d) provide a chemical feedback mechanism that maintains the desired NO levels in response to its consumption or removal (Figure 4B). Therefore, we hope that the data provided in this study stimulates further investigation. However, it is important to caution that (a) the airway $\mathrm{pH}$ may not be homogeneous in vivo as excessive regional acidity and high $\mathrm{HNO}_{2}$ levels could result in airway injury; (b) excessive NO production in the airway could inhibit platelet aggregation, potentially aggravating hemoptysis; (c) $\mathrm{HNO}_{2}$ produces carcinogenic nitrosoamines; (d) the nitrogen redox chemistry in the $\mathrm{CF}$ airway in vivo is exceptionally complex, and several unexpected (and untoward) reactions could result from formation of high airway levels of $\mathrm{HNO}_{2}$; (e) for denitrifying organisms that have intact NIR and NOR activity (including the Aspergillus species), inhaled $\mathrm{NO}_{2}{ }^{-}$could paradoxically promote growth as a nutrient; $(f)$ there are no human data regarding the safety of inhaling near-molar quantities of $\mathrm{NO}_{2}^{-}$, which could have adverse local and systemic effects; and $(\mathrm{g})$ the precise mechanism by which $\mathrm{HNO}_{2}$ affects mucoid $P$. aeruginosa growth is not known. Still, despite these known pitfalls, mucoid $P$. aeruginosa organisms were previously considered impossible to eradicate from the airways of patients with chronic CF lung disease. We believe that our data offer hope that effective treatment strategies can be designed with the ultimate goal of eradicating this formidable foe in CF lung disease.

\section{Methods}

Bacterial culture and enzymatic assays. P. aeruginosa strains used in this study included nonmucoid strain PAO1 (48), CF isolate FRD1 (49), and sputum isolates from CF patients at 5 different North American clinics, totaling 94 strains (Supplemental Table 1). All procedures using human patients were approved by the respective university's Institutional Review Board with respect to informed consent issues. Complementation of FRD1 mucA was achieved by transformation with the plasmid ptacmucA (9). Aerobic starter cultures were grown in $\mathrm{LB}$ ( $10 \mathrm{~g}$ tryptone, $5 \mathrm{~g} \mathrm{NaCl}$, and 5 g yeast extract per liter) at $37^{\circ} \mathrm{C}$. Anaerobic growth was achieved in a Coy anaerobic chamber (Coy Laboratory Products). To support anaerobic respiration, $\mathrm{KNO}_{3}$ and/or $\mathrm{NaNO}_{2}$ (Sigma-Aldrich) were added to the medium. The $\mathrm{pH}$ of the medium was adjusted with $100 \mathrm{mM}$ sodium phosphate (for $\mathrm{pH} 6.5$ ) or $100 \mathrm{mM}$ sodium acetate (for $\mathrm{pH}$ 5.5). To enumerate viable bacteria, serial dilutions were spotted on $\mathrm{LB}$ agar plates. $\mathrm{NO}_{2}{ }^{-}$sensitivity using a filter paper disk assay was performed as previously described (31). NAR, NIR, and NOR activities were measured as described previously (21). Biofilm staining and image acquisition were accomplished as described previously (21).

NO experiments. NO levels were measured polarimetrically using a NO electrode system (Model Apollo 400; World Precision Instruments Inc.) according to the manufacturer's instructions. The NO gas exposure study was performed as described previously (32).

Measurement of $\mathrm{pH}$ in airway secretions. In situ $\mathrm{pH}$ measurements of mucopurulent airway secretions from $\mathrm{CF}$ airways were made by inserting the tip of a $\mathrm{pH}$ microelectrode (MI-413; Microelectrodes Inc.) into mucopurulent secretions within lobar, segmental, and subsegmental bronchi of freshly explanted lungs from $9 \mathrm{CF}$ patients. Lungs were removed at the time of organ transplantation. Duplicate readings at 3 different sites per patient were recorded, and the mean value from each measurement was used for analysis.

Infection of mouse airways. CD1 mice $(n=8)$ were infected with approximately $10^{6} \mathrm{FRD} 1$ or FRD1/pmucA entrapped in agar beads intratracheally as previously described (33). Following 24 hours' incubation, mouse lungs were instilled with $25 \mu$ l of $15 \mathrm{mM} \mathrm{NO}_{2}{ }^{-}$at $\mathrm{pH} 5.5$ (in $0.1 \mathrm{M}^{2}$ acetate buffer) or $\mathrm{pH} 6.5$ 
A

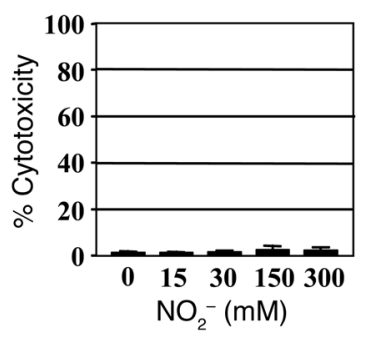

D

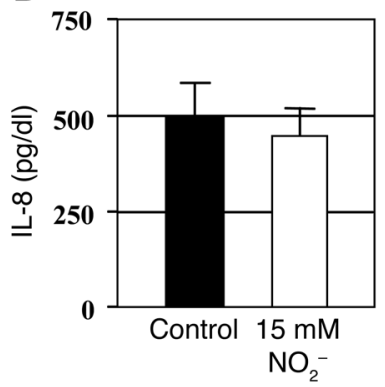

B

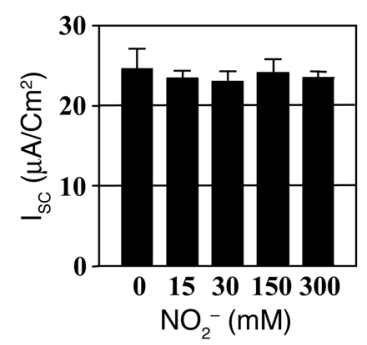

E

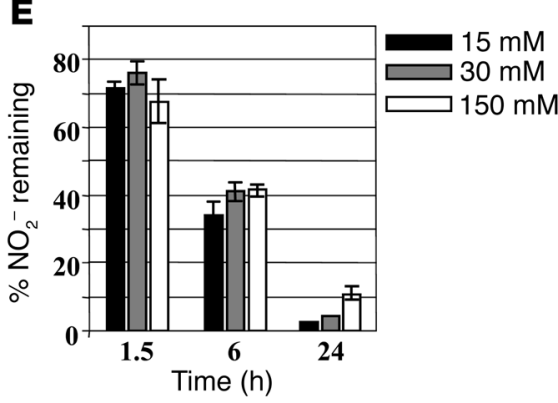

Figure 8

Effect of $\mathrm{NO}_{2}{ }^{-}$on function of cultured human airway epithelia. (A) Culture preparations of human CF airway epithelium (duplicate preparations, $n=3$ ) were exposed apically to $2 \mu \mathrm{l}$ of varying concentrations of $\mathrm{NO}_{2}^{-}$. After 24 hours, lactate dehydrogenase activity in the basolateral media was measured to monitor cytotoxicity. (B) CF airway epithelial cultures were mounted in Ussing chambers and treated with $2 \mu \mathrm{l}$ of liquid containing $\mathrm{NO}_{2}{ }^{-}$at varying concentrations. Transepithelial short circuit current $\left(\mathrm{I}_{\mathrm{sc}}\right.$, in $\left.\mu \mathrm{A} / \mathrm{cm}^{2}\right)$ was measured to monitor change in bioelectric properties. (C) CF airway epithelial cultures (triplicate preparations, $n=4$ ), were treated luminally with $100 \mu \mathrm{l} \mathrm{Krebs}$ bicarbonate Ringer buffer containing $2 \%$ blue dextran and supplemented with either $15 \mathrm{mM} \mathrm{NaCl}$ (control) or $\mathrm{NO}_{2}{ }^{-}$for 24 hours. Transepithelial water flux $\left(J_{v}\right)$ was calculated by measuring blue dextran concentration optically after 24 hours in microaliquots of sampled luminal liquid. (D) IL-8 release assay using primary cultures of CF airway epithelia $(n=4)$ exposed to $15 \mathrm{mM} \mathrm{NO}_{2}{ }^{-}$compared with control cultures. (E) Determination of $\mathrm{NO}_{2}-$ half life on the surface of airway epithelia. The 3 different concentrations of $\mathrm{NO}_{2}{ }^{-}$were applied to airway epithelial cell monolayers, and $\mathrm{NO}_{2}{ }^{-}$levels were assayed at the indicated intervals ( $n=3$ for each measurement). $P=$ NS for all comparisons (ANOVA).

(in $0.1 \mathrm{M}$ phosphate buffer) intranasally twice daily. On the fifth day mice were sacrificed, and the viable bacteria from serially diluted lung homogenates were enumerated. One group of FRD1-infected mice was treated with $15 \mathrm{mM}$ $\mathrm{NO}_{2}^{-}$at $\mathrm{pH} 6.5$ as described above for 16 days to examine whether bacteria develop resistance after prolonged exposure to $\mathrm{NO}_{2}^{-}$. All animal studies were performed in accordance with the protocols approved by the Animal Care Committee of the University of Cincinnati College of Medicine.

In vivo competition assays. In vivo competition assays between mucoid mucA mutant strain FRD1 and FRD1/pmucA embedded in agar beads were carried out by infecting CD1 mice $(n=6)$ intratracheally $\left(2 \times 10^{5}\right.$ bacteria) with a $1: 1$ ratio of each strain as previously described (50). Twenty-four hours after infection, mouse lungs were instilled with $25 \mu \mathrm{l}$ of PBS at $\mathrm{pH} 6.5$ or PBS containing $15 \mathrm{mM} \mathrm{NaNO}_{2}$ at $\mathrm{pH} 6.5$ twice daily for 4 days. Infected lungs were recovered after 6 days for bacterial load and CI calculations. The CI was defined as the output ratio of mutant to wild-type bacteria divided by the input ratio of mutant to wild-type bacteria (51). Thus, if a mutant strain is as competitive as its isogenic wild-type parent, a value of 1 will be achieved. A CI of less than 1 implies that the mutant is not as competitive as the wild-type strain.

Biological properties of airway epithelia in response to $\mathrm{NO}_{2}^{-}$. Primary bronchial epithelial cultures, grown on Transwell $\mathrm{Col}\left(1.13 \mathrm{~cm}^{2}\right.$ surface area) permeable supports (52), were mounted in Ussing chambers (ADInstruments Co.), and

\section{Acknowledgments}

This work was support by NIH Public Health Service grants (AI-40541 and GM-69845) and Cystic Fibrosis Foundation grant HASSETT03P0 to D.J. Hassett. Research at Brookhaven National Laboratory was carried out under the auspices of the US Department of Energy under contract DE-AC02-98CH10886 from the Division of Chemical Sciences, Office of Basic Energy Sciences.

Received for publication February 8, 2005, and accepted in revised form November 29, 2005.

Address correspondence to: Daniel J. Hassett, Department of Molecular Genetics, Biochemistry, and Microbiology, University of Cincinnati College of Medicine, 231 Albert Sabin Way, Cincinnati, Ohio 45267-0524, USA. Phone: (513) 558-1154; Fax: (513) 558-8474; E-mail: Daniel.Hassett@uc.edu.

Sang Sun Yoon's present address is: Department of Microbiology and Molecular Genetics, Harvard Medical School, Boston, Massachusetts, USA. 
1. Boucher, R.C. 2002. An overview of the pathogenesis of cystic fibrosis lung disease. Adv. Drug Deliv. Rev. 54:1359-1371.

2. Yoon, S.S., and Hassett, D.J. 2004. Chronic Pseudomonas aeruginosa infection in cystic fibrosis airway disease: metabolic changes that unravel novel drug targets. Expert Rev. Anti. Infect. Ther. 2:89-101.

3. Coakley, R.D., et al. 2003. Abnormal surface liquid $\mathrm{pH}$ regulation by cultured cystic fibrosis bronchial epithelium. Proc. Natl. Acad. Sci. U. S. A. 100:16083-16088

4. Worlitzsch, D., et al. 2002. Reduced oxygen concentrations in airway mucus contribute to the early and late pathogenesis of Pseudomonas aeruginosa cystic fibrosis airway infection. J. Clin. Invest. 109:317-325. doi:10.1172/JCI200213870.

5. Hassett, D.J., et al. 2002. Anaerobic metabolism and quorum sensing by Pseudomonas aeruginosa biofilms in chronically infected cystic fibrosis airways: rethinking antibiotic treatment strategies and drug targets. Adv. Drug Deliv. Rev. 54:1425-1443.

6. Govan, J.R.W., and Deretic, V. 1996. Microbial pathogenesis in cystic fibrosis: mucoid Psendomonas aeruginosa and Burkholderia cepacia. Microbiol. Rev. 60:539-574

7. Govan, J.R.W., and Fyfe, J.A.M. 1978. Mucoid Pseudomonas aeruginosa and cystic fibrosis: resistance of the mucoid form to carbenicillin, flucloxacillin and tobramycin and the isolation of mucoid variants in vitro. J. Antimicrob. Chemother. 4:233-240.

8. Cabral, D.A., Loh, B.A., and Speert, D.P. 1987. Mucoid Pseudomonas aeruginosa resists nonopsonic phagocytosis by human neutrophils and macrophages. Pediatr Res. 22:429-431.

9. Martin, D.W., et al. 1993. Mechanism of conversion to mucoidy in Pseudomonas aeruginosa infecting cystic fibrosis patients. Proc. Natl. Acad. Sci. U. S. A. 90:8377-8381.

10. Mathee, K., et al. 1999. Mucoid conversion of Psendomonas aeruginosa by hydrogen peroxide: a mechanism for virulence activation in the cystic fibrosis lung. Microbiology. 145:1349-1357.

11. Boucher, J.C., Yu, H., Mudd, M.H., and Deretic, V. 1997. Analysis of mucA mutations in clinical isolates of Pseudomonas aeruginosa: frequency and types in patients with cystic fibrosis and analysis of clearance in a mouse aerosol infection model. Infect. Immun. 65:3838-3846.

12. Anthony, M., et al. 2002. Genetic analysis of Pseudomonas aeruginosa isolates from the sputa of Australian adult cystic fibrosis patients. J. Clin. Microbiol. 40:2772-2778.

13. Hassett, D.J. 1996. Anaerobic production of alginate by Pseudomonas aeruginosa: alginate restricts diffusion of oxygen. J. Bacteriol. 178:7322-7325.

14. Wyckoff, T.J., Thomas, B., Hassett, D.J., and Wozniak, D.J. 2002. Static growth of mucoid Psendomonas aeruginosa selects for non-mucoid variants that have acquired flagellum-dependent motility. Microbiology. 148:3423-3430.

15. Grasemann, H., Gaston, B., Fang, K., Paul, K., and Ratjen, F. 1999. Decreased levels of nitrosothiols in the lower airways of patients with cystic fibrosis and normal pulmonary function. J. Pediatr. 135:770-772.

16. Grasemann, H., Ioannidis, I., de Groot, H., and Ratjen, F. 1997. Metabolites of nitric oxide in the lower respiratory tract of children. Eur. J. Pediatr. 156:575-578

17. Grasemann, H., et al. 1998. Nitric oxide metabolites in cystic fibrosis lung disease. Arch. Dis. Child. 78:49-53.

18. Ratjen, F., Gartig, S., Wiesemann, H.G., and Grasemann, H. 1999. Effect of inhaled nitric oxide on pulmonary function in cystic fibrosis. Respir. Med. 93:579-583.

19. Jones, K.L., et al. 2000. Elevation of nitrotyrosine and nitrate concentrations in cystic fibrosis sputum. Pediatr. Pulmonol. 30:79-85.

20. Gaston, B., et al. 2002. Nitrogen redox balance in the cystic fibrosis airway: effects of antipseudomonal therapy. Am. J. Respir. Crit. Care Med. 165:387-390.

21. Yoon, S.S., et al. 2002. Pseudomonas aeruginosa anaerobic respiration in biofilms: relationships to cystic fibrosis pathogenesis. Dev. Cell. 3:593-603.

22. Fierro, I.M., et al. 1999. Induction of NOS in rat blood PMN in vivo and in vitro: modulation by tyrosine kinase and involvement in bactericidal activity. J. Leukoc. Biol. 65:508-514.

23. Wooldridge, J.L., et al. 2004. NO pathway in CF and non-CF children. Pediatr. Pulmonol. 37:338-350.

24. Goldberg, J.B., and Ohman, D.E. 1984. Cloning and expression in Pseudomonas aeruginosa of a gene involved in the production of alginate. J. Bacteriol. 158:1115-1121.

25. Boucher, J.C., et al. 1996. Two distinct loci affecting conversion to mucoidy in Pseudomonas aeruginosa in cystic fibrosis encode homologs of the serine protease HtrA. J. Bacteriol. 178:511-523.

26. Boucher, J.C., Schurr, M.J., Yu, H., Rowen, D.W., and Deretic, V. 1997. Pseudomonas aeruginosa in cystic fibrosis: role of mucC in the regulation of alginate production and stress sensitivity. Microbiology. 143:3473-3480

27. Goldberg, J.B., Gorman, W.L., Flynn, J.L., and Ohman, D.E. 1993. A mutation in algN permits trans activation of alginate production by alg $T$ in Pseudomonas aeruginosa. J. Bacteriol. 175:1303-1308.

28. Hassett, D.J., et al. 2004. Anaerobic metabolism by Pseudomonas aeruginosa in cystic fibrosis airway biofilms: role of nitric oxide, quorum sensing and alginate production. In Strict and facultative anaerobes: medical and environmental aspects. Horizon Bioscience. Wymondham, United Kingdom. 87-108.

29. Olson, J.S., and Phillips, G.N., Jr. 1996. Kinetic pathways and barriers for ligand binding to myoglobin. J. Biol. Chem. 271:17596.

30. Liu, L., et al. 2001. A metabolic enzyme for S-nitrosothiol conserved from bacteria to humans. Nature. 410:490-494.

31. Lobysheva, I.I., Stupakova, M.V., Mikoyan, V.D., Vasilieva, S.V., and Vanin, A.F. 1999. Induction of the SOS DNA repair response in Escherichia coli by nitric oxide donating agents: dinitrosyl iron complexes with thiol-containing ligands and S-nitrosothiols. FEBS Lett. 454:177-180.

32. Hurst, J.K., and Lymar, S.V. 1997. Toxicity of peroxynitrite and related reactive nitrogen species toward Escherichia coli. Chem. Res. Toxicol. 10:802-810.

33. Zhu, L., Gunn, C., and Beckman, J.S. 1992. Bactericidal activity of peroxynitrite. Arch. Biochem. Biophys. 298:452-457.

34. Hassett, D.J., Schweizer, H.P., and Ohman, D.E. 1995. Pseudomonas aeruginosa sodA and $\operatorname{sodB}$ mutants defective in manganese- and iron-cofactored superoxide dismutase activity demonstrate the importance of the iron-cofactored form in aerobic metabolism. J. Bacteriol. 177:6330-6337.

35. Garrett, E.S., Perlegas, D., and Wozniak, D.J. 1999. Negative control of flagellum synthesis in Pseudomonas aeruginos a is modulated by the alternative sigma factor AlgT (AlgU). J. Bacteriol. 181:7401-7404.

36. O'Toole, G.A., and Kolter, R. 1998. Flagellar and twitching motility are necessary for Pseudomonas aeruginosa biofilm development. Mol. Microbiol. 30:295-304.
37. Lau, G.W., Ran, H., Kong, F., Hassett, D.J., and Mavrodi, D. 2004. Pseudomonas aeruginosa pyocyanin is critical for lung infection in mice. Infect. Immun. 72:4275-4278.

38. Sparkman, L., and Boggaram, V. 2004. Nitric oxide increases IL-8 gene transcription and mRNA stability to enhance IL-8 gene expression in lung epithelial cells. Am. J. Physiol. Lung Cell Mol. Physiol. 287:L764-L773.

39. Pedersen, S.S., Hoiby, N., Espersen, F., and Koch, C. 1992. Role of alginate in infection with mucoid Pseudomonas aeruginosa in cystic fibrosis. Thorax. 47:6-13.

40. Firoved, A.M., Wood, S.R., Ornatowski, W., Deretic, V., and Timmins, G.S. 2004. Microarray analysis and functional characterization of the nitrosative stress response in nonmucoid and mucoid Pseudomonas aeruginosa. J. Bacteriol. 186:4046-4050.

41. Woodmansee, A.N., and Imlay, J.A. 2003. A mechanism by which nitric oxide accelerates the rate of oxidative DNA damage in Escherichia coli. Mol. Microbiol. 49:11-22.

42. Soum, E., and Drapier, J.C. 2003. Nitric oxide and peroxynitrite promote complete disruption of the [4Fe-4S] cluster of recombinant human iron regulatory protein 1. J. Biol. Inorg. Chem. 8:226-232.

43. Schopfer, F.J., Baker, P.R., and Freeman, B.A. 2003. NO-dependent protein nitration: a cell signaling event or an oxidative inflammatory response? Trends Biochem. Sci. 28:646-654.

44. Mayburd, A.L., and Kassner, R.J. 2002. Mechanism and biological role of nitric oxide binding to cytochrome c'. Biochemistry. 41:11582-11591.

45. Spallarossa, A., et al. 2003. Inhibition of Azotobacter vinelandii rhodanese by NO-donors. Biochem. Biophys. Res. Commun. 306:1002-1007.

46. Hunt, J.F., Gaston, B.J., and Ricciardolo, F. 2004. Acid stress in the airway. J. Allergy Clin. Immunol. 84:731-765.

47. Hunt, J.F., et al. 2000. Endogenous airway acidification. Implications for asthma pathophysiology. Am. J. Respir. Crit. Care Med. 161:694-699.

48. Holloway, B.W. 1969. Genetics of Pseudomonas. Bacteriol. Rev. 33:419-443.

49. Ohman, D.E., and Chakrabarty, A.M. 1981. Genetic mapping of chromosomal determinants for the production of the exopolysaccharide alginate in a Pseudomonas aeruginosa cystic fibrosis isolate. Infect. Immun. 33:142-148

50. Lau, G.W., Hassett, D.J., Ran, H., and Kong, F. 2004. The role of pyocyanin in Pseudomonas aeruginosa infection. Trends Mol. Med. 10:599-606.

51. Lau, G.W., et al. 2001. A functional genomic analysis of type 3 Streptococcus pneumoniae virulence. Mol. Microbiol. 40:555-571.

52. Matsui, H., et al. 1998. Evidence for periciliary liquid layer depletion, not abnormal ion composition, in the pathogenesis of cystic fibrosis airways disease. Cell. 95:1005-1015

53. Grubb, B.R., Paradiso, A.M., and Boucher, R.C. 1994. Anomalies in ion transport in CF mouse tracheal epithelium. Am. J. Physiol. 267:C293-C300.

54. Green, L.C., et al. 1982. Analysis of nitrate, nitrite, and $\left[{ }^{15} \mathrm{~N}\right]$ nitrate in biological fluids. Anal. Biochem. 126:131-138.

55. Coddington, J.W., Hurst, J.K., and Lymar, S.V. 1999. Hydroxyl radical formation during peroxynitrous acid decomposition. J. Am. Chem. Soc. 121:2438-2443.

56. Konorev, E.A., Tarpey, M.M., Joseph, J., Baker, J.E., and Kalyanaraman, B. 1995. Nitronyl nitroxides as probes to study the mechanism of vasodilatory action of nitrovasodilators, nitrone spin traps, and nitroxides:role of nitric oxide. Free Radic. Biol. Med. 18:169-177. 